\title{
The Reactions between Polycations Carrying Charges in the Chain Backbone and Polycarboxylic Acids
}

Yoshihito Osada, Koji $\mathrm{Abe}_{\mathrm{BE}}$ and Eishun Tsuchida

Department of Polymer Chemistry, Waseda University; Nishiohkubo, Shinjuku-ku, Tokyo 160 Japan

The formation reactions of polyion complexes between polycations carrying charges in the chain backbone and polycarboxylic acids (e.g., polymethacrylic acid, polyacrylic acid and polyitaconic acid) were studied by means of potentiometric titration. In these systems polycations release much more hydrogen ions than low molecular weight cations, so it was found that the chain lenght, i.e., the numder of charged sites, played an important role in the complexation. By using different polycarboxylic acids, it was shown that, in addition to the Coulombic forces, the hydrophobic bonds also influenced complexation. The $n^{\prime}$ value of the Henderson-Hasselbach equation, which shows the parameter of the intramolecular interaction of polymethacrylic acid, was found to be 2.3. However, this value decreased to 1.4 when the polycations were added to the polymethacrylic acid solution. This phenomenon shows that the electrostatic repulsion between neighboring dissociated carboxylic groups is diminished efficiently by the complexation. From these results, it is assumed that the dissociation constant and hydrophobicity of polymer chains control the ability of complexation.

（日本化学会誌, 1973, p. 2222 2226)

\section{ポリイオンコンプレックスの生成条件と構造122}

(1972 年 12 月 18 日受 理)

長田義仁・阿部康次・土田英俊*

主鎖荷電型ポリカチオンとポリカルボン酸（ポリメタクリル酸，ポリアクリル酸，ポリイタコン酸） の間のポリイオンコンプレックス生成反応機構を, 系の電位差滴定, 電導度滴定, 粘度測定から検討し た。コンプレックスの組成はポリカルポン酸の解離度で決まる。ポリカルボン酸の解離度は $10^{-4} \sim 10^{-3}$ $\mathrm{mol} / l$ の濃度範围で通常数パーセントであるが，ポリカチオンが共存すると $20 \%$ 近くまで解離する。 このため両者を混合して得られるポリイオンコンプレックスは，イオン席の単位モル比で［カルボン 酸 $] /[$ チオン $] \simeq 5$ の組成となる。この系にアルカリを添加して解離度を大きくすると、コンプレック ス組成は連続的に変化し等モル組成物が得られる。

これらの結果から生成するポリイオンコンプレックスの構造は環状から梯子状まで任意に連続変化さ せ得ることが結論され，これがメカノケミカルシステムの一例であると推定した。

\section{1 緒言}

著者らはさきに，ポリイオンコンプレックス生成反応飞おい て，電荷数（すなわち鎖長）や柾水結合が重要な因子となってい ることを明らかにした2)。本報では，ポリカルポン酸と主鎖荷電 型ポリカチオンとが生成するコンプレックスの組成や構造が，ポ

1）この報文を“ポリイオン重合鎖に関する研究(第 10 報)” とする.

2）前報(第 9 報)，長田義仁，阿部康次，士田英俊，日化， 1973, 2219.

* 早稲田大学理工学部, 160 東京都新宿区西大久保
リカルボン酸の解離度と密接な関連を有していることを見いだし たのでここに報告する。

験

\section{1 試薬の調整}

使用したポリカルボン酸類や溶媒は前報2) と同様の方法で調整 した。ポリカチオン類は文献3) の方法で精製使用した。ポリカル ボン酸の中和度 $(\alpha)$ は $0.1 \mathrm{~N} \mathrm{NaOH}$ 水溶液を使用して調整し

3）土田英俊，真田 茥，篠原 功，工化，74，756，760，1449 (1971) ; Makromol. Chem., 151, 207(1972)； 155, 35 (1972). 
た。

2.2 コンプレックス生成と電導度測定

窒素気流中, 温度 $25^{\circ} \mathrm{C}$ で成分ポリマーの水溶液（濃度; $5 \times$ $\left.10^{-4} \mathrm{base} \cdot \mathrm{mol} / \mathrm{l}\right)$ をかきまぜながら，他方成分のポリマー水溶夜 (濃度; $5 \times 10^{-3}$ base $\cdot \mathrm{mol} / l$ ) をゆっくり滴下し，それぞれの混合 比に㨟けるコンプレックス水溶液の電導度を白金一白金黒電極電 導度滴定装置（Shimadzu，CM-30）を用いて測定した。滴下後 平衡状態になるまで少なくとも4 分間栺置してから測定した。コ ンプレックスの組成と樽造におよぼす生成条件の影響を検討する ために，各成分ポリマー水溶液の所定量を一時に混合して測定す る方法も試みた。

\section{3 その他の測定}

水素イオン浱度は $\mathrm{pH}$ メーター（日立一堀場製 M-5 型, ガラ ス単一電極 $)$ により, 粘度は $30( \pm 0.1)^{\circ} \mathrm{C}$ で変型 Ubbelohde 粘

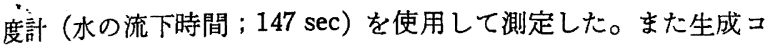
ソプレックスは $50^{\circ} \mathrm{C}$ で真空乾燥後, 恒量に達するのをまって元 素分析にかけ，組成を決定した。

\section{3 結果と考察}

\section{1 成分ポリマー種とコンプレックス組成の関係}

前報で述べたように，コンプレックス生成にともなって当量電 尊度の大きな低分子イオンが放出されるはずであるから，反応系 の電導度変化を測定して反応が追跡できる。

因1(A) は中和度 0 に扣いて，ポリメタクリル酸（以下PMAA と略記する）に各種ポリカチオン（前報参照)）を滴下していった さいの電遒度変化を示したものである。ポリカチオン種に関係な く、いずれも [ポリカチオン]/[PMAA] $=0.2$ に括いて滴定曲線 の不連続点,つまり当量点が観察される。これはコンプレックス 生成にともなって当量電導度の大さい低分子イオン，ここでは $\mathrm{H}^{+}, \mathrm{Cl}^{-}$が遊離されるため系の電遒度が急速な増加を示すが，こ の当量点以後の電遒度増加は, 過剩に存在するポリカチオンの寄 与が主となるためであろら。一方，ほとんどのカルボキシル基が 解離している $(\alpha=1.0)$ PMAA では，図 1（B）に見られるよ 5に不連続点は組成比 1.0 亿観測される。この系では遊離される 低分子が $\mathrm{NaCl}$ であり，その当量電導度は小さい（無限希釈イオ ン当量電導度 ${ }^{4)} 25^{\circ} \mathrm{C}: \mathrm{H}^{+} 349.7, \mathrm{Na}^{+} 50.1, \mathrm{Cl}^{-} 76.3\left[\Omega^{-1}\right.$. $\left.\left.\mathrm{cm}^{2} \cdot \mathrm{eq}^{-1}\right]\right)$ 。したがって $\alpha=0$ の場合と異なり, 当量点前の電 導度增加は小さくなる。これと同じよらな系でポリカチオン種を 変えて反応させても，コンプレックスの組成に差は認められない が，これはポリカチオンがいずれも $p K 3$ 程度の強電解質である ためと考えられる。

つぎに $3 \mathrm{X}$ ポリマーに対して，ポリアクリル酸（以下 PAA と略記する), ポリイタコン酸（以下 PIA と略記する）を反応さ せ、これがコンプレックス組成におよぽす影響を検討した。その 結果は $\alpha=0$ に括いて，当量点は $[3 \mathrm{XX}] /[\mathrm{PAA}]=0.25,[3 \mathrm{X}] /$ $[\mathrm{PIA}]=0.32$ に観測された。これはポリカルボン酸の解離定数 $\left(p K_{\mathrm{PMAA}_{1}}: 7.0, p K_{\mathrm{PAA}}: 6.4, p K_{\mathrm{PIA}}: 5.8\right)$ が $\mathrm{PMAA}<\mathrm{PAA}<$ PIA の順となっていることに関係がある。これらポリカルボン 酸は， $\alpha=0$ の条件のとき，単独では数\%のカルボキシル基が解 離するのみであるのに対し, ポリカチオンが共存すると解離は促 進され0.2 0.32 にまで達するが，この現象は前報で述べた結論 4）日本化学会編, “化学便筧”, 丸善 (1966) p. 862.

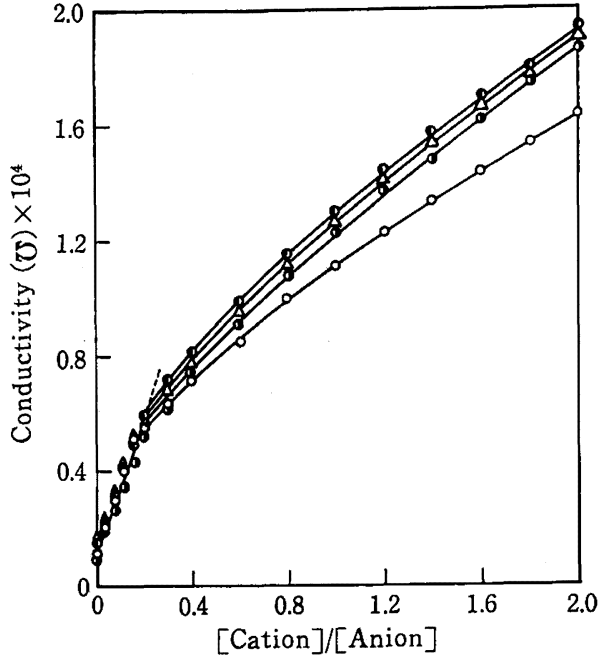

Fig. 1-(A) Effect of polycations on the composition of complexes

Polyanion : PMAA $(\alpha=0)$

Polycations -

$\mathrm{O}: 2 \mathrm{X}, \circlearrowleft: 3 \mathrm{X}, \bigcirc: 6 \mathrm{X}, \triangle \mathrm{XX}$

$[\mathrm{PMAA}]=5 \times 10^{-4} \mathrm{~mol} / \mathrm{l}$

$[2 \mathrm{X}]=[3 \mathrm{X}]=[6 \mathrm{X}]=[\mathrm{XX}]=5 \times 10^{-3} \mathrm{~mol} / l$

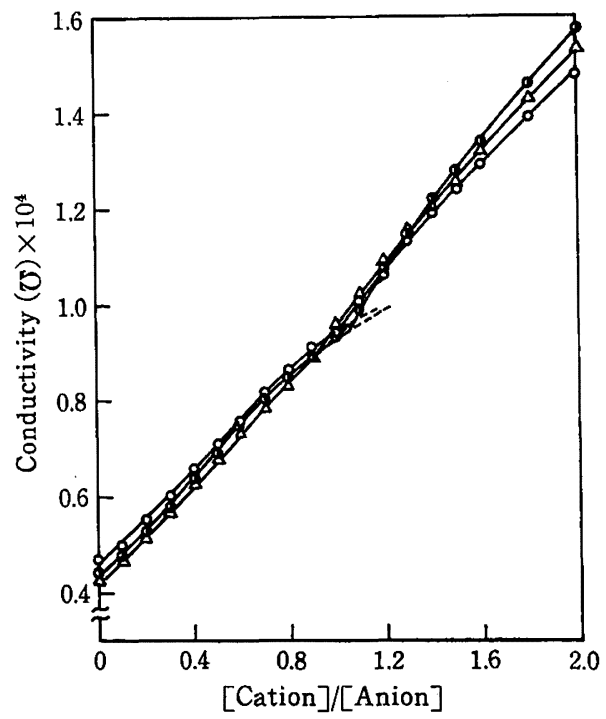

Fig. 1-(B) Effect of polycations on the composition of complexes

Polyanion : PMAA $(\alpha=1.0)$

Polycations$\mathrm{O}: 2 \mathrm{X}, \circlearrowleft: 3 \mathrm{X}, \triangle: \mathrm{XX}$

$[\mathrm{PMAA}]=5 \times 10^{-4} \mathrm{~mol} / \mathrm{l}$ $[2 \mathrm{X}]=[3 \mathrm{X}]=[\mathrm{XX}]=5 \times 10^{-3} \mathrm{~mol} / \mathrm{l}$

とも一致する。すなわちポリカチオンがポリカルボン酸の対イオ ンとして存在すると，PMAA の $\alpha$-メチル基間柾水結合を破壊 し，また解離したカルボキシル基間の分子内静電反発す小さくな るのでポリカルポン酸の解離は促進される。 $\alpha=1.0$ の条件下で は，ポリカルポン酸は $3 \mathrm{X}$ ポリマーと $1: 1$ のとき当量点を示し， コンプレックスは等モル組成となり，ポリカルボン酸の種類に影 響されない。以上の結果は表 1 にまとめて示した。 
Table 1 Effect of polyelectrolytes on the composition of complexes

\begin{tabular}{|c|c|c|c|c|c|}
\hline Polyanion & olycation & $2 X$ & $3 X$ & $6 \mathrm{X}$ & $\mathrm{XX}$ \\
\hline \multirow{3}{*}{$\alpha=0$} & ( PMAA & 0.18 & 0.20 & 0.20 & 0.19 \\
\hline & PAA & - & 0.24 & - & - \\
\hline & PIA & - & 0.32 & - & - \\
\hline \multirow{2}{*}{$\alpha=1.0$} & $\{$ PMAA & 1.0 & 1.0 & - & 0.95 \\
\hline & I PIA & - & 1.0 & - & - \\
\hline
\end{tabular}

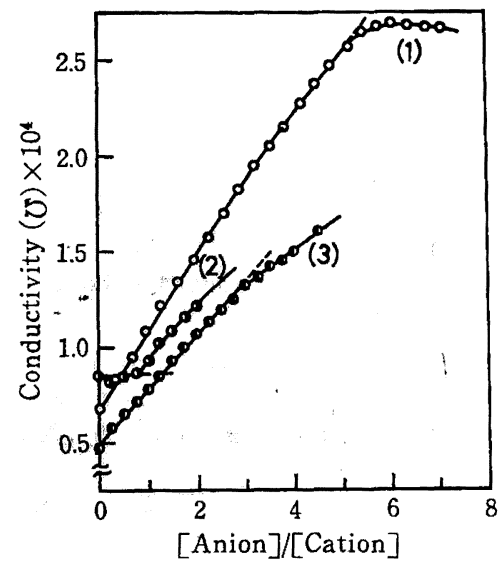

Fig. 2 Effect of the reaction condition on the composition of the complexes

PMAA $(\alpha=0, \alpha=1.0)$ were dropped into $3 \mathrm{X}$ slowly: $\bigcirc \alpha=0, \bigcirc \alpha=1.0$

PMAA $(\alpha=0)$ was dropped into $3 \mathrm{X}$ rapidly : 0 $[\mathrm{PMAA}]=5 \times 10^{-4} \mathrm{~mol} / \mathrm{l}$

$[3 \mathrm{X}]=5 \times 10^{-3} \mathrm{~mol} / \mathrm{l}$

\section{2 混合順序とコンプレックス組成の関係}

前節 (3.1) に扣いて，ポリカルボン酸溶液にポリカチオン溶液 を滴下したさいのコンプレックス組成について検討したが，ここ では混合順序を逆にした場合について考察する。すなわち $3 \mathrm{X}$ 溶 夜に PMAA 溶夜を滴下していったさいの電導度変化をみると図 2 のよ5になる。不連続点は, $\alpha=0$ のとき $[\mathrm{PMAA}] /[3 \mathrm{X}]=$ $5.0, \alpha=1.0$ のとき $[\mathrm{PMAA}] /[3 \mathrm{X}]=1.05$ となり, 混合順序は コンプレックス組成に影響していない。

\section{3 混合速度とコンプレックス組成の関係}

ポリイオンコンプレックスの生成はイオン間反応であり，おの おののイオン席間の結合速度はきわめて速い。各成分ポりマー水 溶液の所定量を一時に混合して得たコンプレックス溶液の電尊度 を図 2-（3）にまた粘度測定を図3に示した。これまで述べて きたような, 平衡状態をつくりながらゆっくり滴下した場合と異 なり, 中和度 0 の条件で $[3 \mathrm{X}] /[\mathrm{PMAA}]=0.33$ に当量点が観測 される。これは両者の溶液を一時に混合するために，それぞれの イオン席は近傍にある基同志が不規則に結合し，このため全部の イオン席が完全に反応する前に急激なコンホメーション変化を起 こして相分離し，結合していない基を残したまま沈股するすのと 考えられる。実際この系では電導度変化が小さく、ミクロイオン の遊離が㧕制されていることを示している。

3.4 ポリカルボン酸の解離度とコンプレックス組成

$0.1 \mathrm{~N} \mathrm{NaOH}$ を添加してカルボキシル基の解離度を変化させた

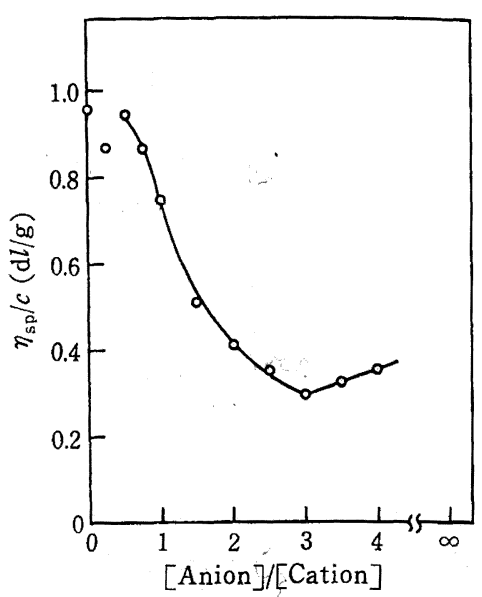

Fig. 3 The viscosity change of PMAA $(\alpha=0)-2 \mathrm{X}$ complex solution

[PMAA] $=1.4 \times 10^{-1} \mathrm{~mol} / \mathrm{l}$

$[2 \mathrm{X}]=1.4 \times 10^{-1} \mathrm{~mol} / l, 30.0^{\circ} \mathrm{C}$

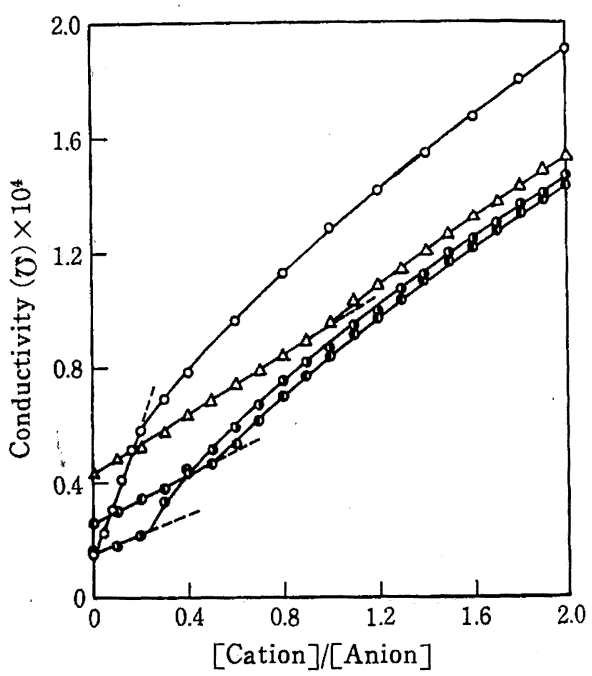

Fig. 4-(A) Dependence of composition of complexes on degree of neutralization

Polycation : XX

Polyanion : PMAA

$$
\alpha=\bigcirc 0, \bigcirc 0.2, \bigcirc 0.5, \triangle 1.0
$$

[PMAA] $=5 \times 10^{-4} \mathrm{~mol} / \mathrm{l}$

$[\mathrm{XX}]=5 \times 10^{-3} \mathrm{~mol} / l, 25^{\circ} \mathrm{C}$

PMAA 水溶液に, XX ポリマー水溶液を滴下反応させるさいの， 系の電尊度变化は図 4-(A) の上5になる。中和度 $\alpha$ が 0 から 1 まで変化するにしたがって，コンプレックス組成は 0.2 から 1.0 まで変化していく。

PMAA または PAA 水溶液に $3 \mathrm{X}$ 溶液を滴下していくときの 水素イオン濃度変化を図 4(B), (C) 飞示した。図 4 (B) に 颃いて， $\alpha=0$ の場合，初期段階に括いて急激な水素イオン濃度 の増加がみられ， $[3 \mathrm{X}] /[\mathrm{PMAA}] \simeq 0.20$ で飽和する傾向を示 す。この急激な $\mathrm{pH}$ 変化は明らかにコンプレックス生成にとすな $5 \mathrm{HCl}$ 遊離に基つくるのと考えてよい。アルカリ添加系では所 定量のポリカチオン添加後にはじめて $\mathrm{pH}$ 変化が起こり，この 変化点の混合比は PMAA の中和度に関係する。これはPMAA 


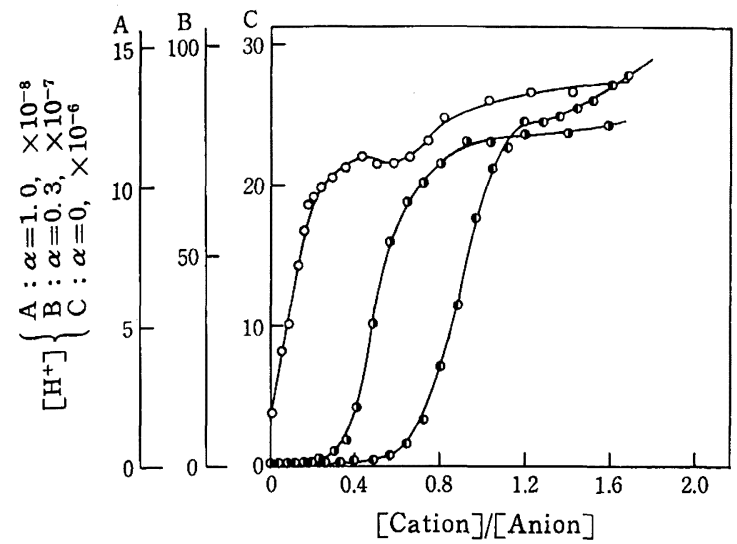

Fig. 4-(B) Dependence of composition of complexes on degree of neutralization

Polycation : $3 \mathrm{X}$

Polyanion : PMAA

$$
\alpha=\bigcirc 0, \bigcirc 0.3, \bigcirc 1.0
$$

$[\mathrm{PMAA}]=5 \times 10^{-4} \mathrm{~mol} / \mathrm{l}$

$[3 \mathrm{X}]=5 \times 10^{-3} \mathrm{~mol} / l, 25^{\circ} \mathrm{C}$

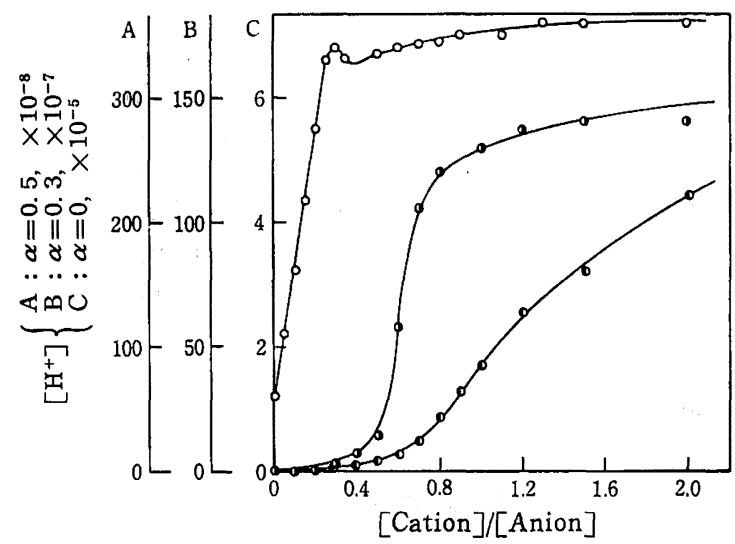

Fig. 4-(C) Dependence of composition of complexes on degree of neutralization

Polycation : $3 \mathrm{X}$

Polyanion : PAA

$$
\alpha=00,00.3, \circlearrowleft 0.5
$$

$[\mathrm{PAA}]=5 \times 10^{-4} \mathrm{~mol} / \mathrm{l}$

$[3 \mathrm{X}]=5 \times 10^{-3} \mathrm{~mol} / \mathrm{l}, 25^{\circ} \mathrm{C}$

にめるカルボキシル基が中和度にしたがった部分的な塩を形成し ているため，コンプレックス生成は物もに中和反応の形で $\mathrm{NaCl}$ を遊離しながら進行する。したがってこの間 $\mathrm{pH}$ 変化は生起せ ず，中和反応終了にともなって過剩添加の $3 \mathrm{X}$ 溶液に基つく $\mathrm{pH}$ 上昇を認めるのである。ちなみに $3 \mathrm{X}$ の $0.001 \mathrm{~N}$ 水溶液は $\mathrm{pH}$ 3.2 を示す。したがって，急激な $\mathrm{pH}$ 変化を示す点がコンプレッ クス組成を示すことになる。PAA の系でも同様な関係が得られ る。これらの結果は表 2 拈よび図 5 亿まとめて示してある。ポリ カルポン酸の中和度にしたがってコンプレックス組成は，[カチ オン]/[PMAA] が 0.18〜0. 95, [カチオン]/[PAA] が 0.24〜 0.99 の範囲で変化することがわかる。これらの值は電導度滴定 曲線から求めた値とまったくよく一致する。さらに図 5 には，ポ リカチオンが共存した系の PMAA の解離定数 $\left(p K_{\mathrm{PMAA}}=5.3\right)$
Table 2 Dependence of composition of complexes on degree of neutralization

\begin{tabular}{ccccccccc}
$\alpha$ & 0 & 0.1 & 0.2 & 0.3 & 0.5 & 0.7 & 0.8 & 1.0 \\
\hline $\begin{array}{c}{[3 \mathrm{X}] /} \\
{[\mathrm{PMAA}]}\end{array}$ & 0.18 & 0.39 & 0.47 & 0.60 & 0.76 & 0.80 & 0.88 & 0.95 \\
$\begin{array}{c}{[3 \mathrm{X}] /} \\
{[\mathrm{PAA}]}\end{array}$ & 0.24 & - & - & 0.63 & 0.81 & - & - & 0.99
\end{tabular}

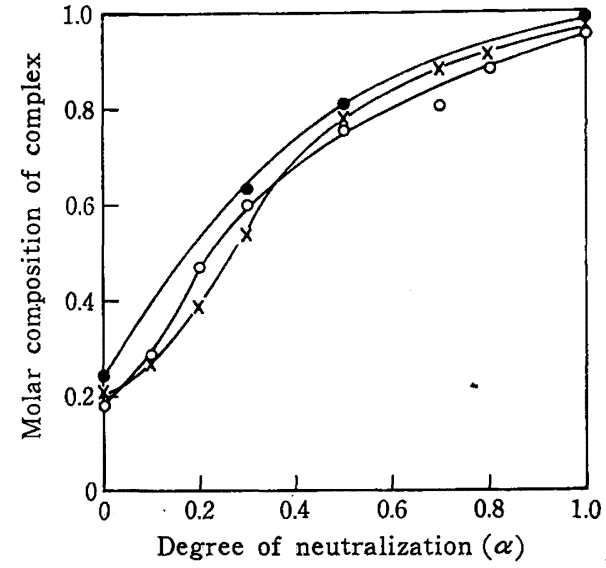

Fig. 5 Relationship between composition of complexes and degree of neutralization

$O$ : PMAA-3 X, : PAA-3 X,

$X$ : Calculated from the $p K$ of PMAA

\begin{tabular}{|c|c|c|c|c|}
\hline & & $\mathrm{C}(\%)$ & $\mathrm{H}(\%)$ & $\mathrm{N}(\%)$ \\
\hline $\begin{array}{l}\text { PMAA-2X } \\
(\alpha=0)\end{array}$ & $\begin{array}{l}\text { Found } \\
\text { Calcd. }\end{array}$ & $\begin{array}{l}58.23 \\
60.09\end{array}$ & $\begin{array}{l}8.16 \\
8.59\end{array}$ & $\begin{array}{l}2.46 \\
2.60\end{array}$ \\
\hline $\begin{array}{c}\text { PMAA-2X } \\
(\alpha=1.0)\end{array}$ & $\begin{array}{l}\text { Found } \\
\text { Calcd. }\end{array}$ & $\begin{array}{l}67.17 \\
67.50\end{array}$ & $\begin{array}{l}6.85 \\
8.21\end{array}$ & $\begin{array}{l}6.85 \\
7.02\end{array}$ \\
\hline
\end{tabular}

Table 3 Elementary analysis of complexes

をあとにして，各中和度に和ける PMAA の解離度を計算し，解 離したカルボキシル基がすべてポリカチオンとコンプレックスを 形成し得るむのと仮定して得られるコンプレックス組成曲線を示 したが, これは PMAA とポリカチオンのコンプレックス組成と よく一致している。

また表 3 には生成したコンプレックスの元素分析絬 果を示し た。ここで計算值は，前に述べた滴定曲線から得られたコンプレ ックス組成の示す值,すなわち $\alpha=0$ においては [カチオン]/ $[\mathrm{PMAA}]=0.2, \alpha=1.0$ に拈いては [カチオン]/[PMAA] $=1.0$ を基準に求めた数值である。而者の值はよく一致して扣り，さき に述べた反応と組成に関する推論が正しいことがわかるし，水素 イオン濃度を変化させて，コンプレックス組成を決定できること がわかる。

以上からポリカルポン酸の解離度 $\left(\alpha^{\prime}\right)$ の変化にともなって, コンプレックス組成に関し次式が成立する。式（1）の関係はポ

$$
\alpha^{\prime}=[\text { ポリカチン }] /[\text { ポリカルポン酸 }]
$$

リカチオンが完全解離した強電解質であれば，ここに述べた主鎖 荷電型ポリカチオンにかぎらず，つねに成立する。こらしたコン プレックスの連続的な組成変化は模型的な表現をとれば, 式 (2) に示すようにプロトンの出入をともなら環状と梯子状 (loop and 


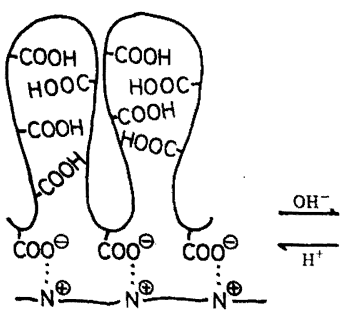

環状

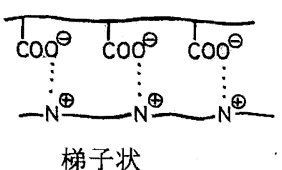

梯子状 ladder）構造をとるものと思われる。解離度の小さい領域では， ポリカルボン酸の静電反発す小さく, かつ主鎖す比較的柔軟であ るからランダムコイルをとりやすいのに対し，ポリカチオンは主 鎖にイオン席を有する強電解質であり，鎖員にキシリレン基など
比較的硬い構造をるつため，かなり広い $\mathrm{pH}$ 域にわたり延伸され たコンホメーションをとるであろら。このためポリカルボン酸の 解離度が小さい領域では, 未解離カルボキシル基が結合に関与し ない式（2）の左辺に示した環状構造をとるるのと考兄られる。 しかし解離度が増加するにともなってポリカルボン酸内の静電反 発は増大し，次第に拡がったコンホメーションをとるよらにな り，すべてのカルポキシル基が解離するときには，イオン席がポ リカチオンと対になって結合した，式（2）の右辺に示したよう な梯子状棈造をとるものと推定される。このような構造の翼なっ たコンプレックス形成の熱力学的, あるいは速度論的取り扱い, さらにはコンプレックスのメカノケミカル反応に関する検討は今 後の問題であろら。

\title{
The Composition of Polyion Complex
}

\author{
Yoshihito Osada, Koji $\mathrm{AbE}_{\mathrm{B}}$ and Eishun Tsuchida \\ Department of Polymer Chemistry, Waseda University; \\ Nishiohkubo, Shinjuku-ku, Tokyo 160 Japan
}

The mechanism of the formation of polyion complexes between polycations carrying charges in the main-chain and polycarboxylic acids (e.g., polymethacrylic acid, polyacrylic acid and polyitaconic acid) were studied by potentiometric titration, conductometric titration and viscosity measurement. The compositions of the complexes were found to be controlled by the degree of the dissociation of the polycarboxylic acids. Polycarboxylic acids usually dissociate only in a few percents at a concentration range of $10^{-4} \sim 10^{-3} \mathrm{~mol} / l$, while the degree of dissociation were increased up to about $20 \%$ in the prefence of the polycations. The composition of the polyion complexes which were obtained from the polyanion and polycation solutions was in a ratio about $5: 1$ of the repeating units of the ionic sites, i.e., [polycarboxylic acid]/[polycation]. When the degrees of dissociation of polycarboxylic acids were increased by addition of alkaline solution, the compositions of the complexes were found to be equimolar.

From these results, it was assumed that the polyion complexes which were formed in these systems could take any forms from "loop" to "ladder" succesively and arbitrarily. 